\title{
«Dios hará inquisición de vuestros juicios»: Antonio Enríquez Gómez' Search for Justice
}

\author{
Constance H. RosE \\ Northeastern University, Boston
}

One theme which surely unites the work of Antonio Enríquez Gómez -the lyric and epic poetry, the satires in poetry and in prose, the picaresque novel, the political treatises and the fifty or more plays- is his search for justice ${ }^{1}$ : personal justice, earthly justice and finally divine justice. Today I intend to examine certain aspects of two of his plays and two of his prose works: the eminently serious Luis dado de Dios a Luis y Ana: Samuel dado de Dios a Elcaná y Ana and the comic Inquisición de Lucifer y Visita de todos los diablos ${ }^{2}$, in light of the above statement.

In his dramatic works, approximately a third of which were written in Spain before his flight to France in 1637, Enríquez Gómez often depicts a protagonist who is a stranger in a strange land, an outsider who must struggle against all odds, who at first may be welcomed but who is then the target of evil and envious courtiers. Such is the case with Fernán Méndez Pinto (in the play of the same name ${ }^{3}$ ), who, shipwrecked off the coast of China, becomes an advisor to the king, but, as a target of court intrigue,

1 Others who have also observed Enríquez Gómez' concern with justice include GARCía VAldECASAS ANDRADE (1971) and KRAMER-HELlinX (1992).

2 All references to this work imply the edition of ROSE - KERKHOF (1992), the only complete edition of the recently discovered manuscript.

3 Antonio Enríquez Gómez, Fernán Méndez Pinto, Comedia famosa en dos partes, Intro. and Ed. COHEN, Rogers and Rose (1974), is based on the Peregrinação of the sixteenth-century Portuguese adventurer. See also RosE 1973 and 1982. 
is arrested and sentenced to death, for crimes he has not committed. In accordance with the Chinese legal system, however, he is allowed to plead his case in court and does so so effectively that he is not only released but is rewarded by the sage oriental monarch and elevated to the rank of captain of the king's guard (Rose 1982).

Another example of the way in which good triumphs over evil when true justice is dispensed occurs in a later play, Los filósofos de Grecia, published in 1662 under the name of Fernando de Zárate, when its author, having secretly returned to his homeland, was confined to an inquisitional cell in Seville, accused of Judaizing. In this amusing comedy, which takes place in ancient Greece, Demócrito and Heráclito ${ }^{4}$, advisors to the queen, are denounced by scheming courtiers who accuse them of treason; the philosophers are jailed and sentenced to death, but through their own efforts, they are ultimately exonerated and rewarded for their wisdom and loyalty by the grateful sovereign.

It is not difficult to see in these plays a paradigm of the medieval monarch who protected the court Jews whose wisdom and skill he valued; equally it is not difficult to see the situation as one of wish fulfilment in which Enríquez Gómez himself brings to the attention of Spanish audience/readers his success in a foreign land where his talents are appreciated and where the ruler relies upon his advice (Rose 1973).

To sustain such an impression, Enríquez Gómez, in works written in his Gallic haven, cast himself as a majordomo of the French king and a member of the royal order of Saint Michel. To date these honors cannot be substanciated and may be one more example of wish fulfilment enhanced by self-advertising, one more example of the author's ability to create a variety of roles for himself ${ }^{5}$.

\footnotetext{
${ }^{4}$ Enríquez Gómez frequently alluded to these philosophers whose reactions of tears and laughter mirrored his own (ROSE 1982; GARCía GómEZ 1984). García Gómez, however, does not believe that this play is a comedy.

5 Enríquez Gómez, for example, attributes such honors to himself in Luis dado de Dios (1645), La política angélica (1647) and La torre de Babilonia (1649). MCGAHA (1991) is convinced of the veracity of this title, but neither AMIEL (1977) nor I (ROSE 1973), who have personally carried out archival research in France, have as yet been able to document these claims. The Spaniard was, however, made a «sire de la Ville de Rouen», an honor that related more to his initial success as
} 
In plays, poetry and prose alike, it is clear that Enríquez Gómez sought the king's ear and wished to effect policy. Indeed, one wonders, did he see himself as a contemporary court Jew whose monarch would respect him and value his counsel, protect and reward him?

Enríquez Gómez continued in his advisory role in Luis dado de Dios, a political treatise published in Paris in 1645 during its author's exile. It is a «reloj de príncipes» or mirror of princes, of sorts, in which the author likens Louis XIII and his wife, Anne of Austria, to the parents of Samuel, and Louis XIV, who was six at the time, to Samuel, the Biblical leader and lawgiver.

As Enríquez Gómez was autodidact, it is uncertain whether or not he read Hebrew ${ }^{6}$, although he was acquainted with Jewish prayers and practices; and although he was an avid reader, surely he knew little Latin and less Greek. Therefore, his route to the Bible was through the vernacular. Unlike his Manchegan ancestors, who provided themselves with a then contemporary work, Fray Juan de Dueñas's Espejo de Consolación de Tristes, in order to have access to Old Testament stories ${ }^{7}$, and unlike his daughter Leonor who, in order to help converts in Rouen return to Judaism, was reported to have used the Ferrara Bible (Révah 1962), reprinted in nearby Amsterdam ${ }^{8}$, Enríquez Gómez selected

a merchant than to his would-be role as counsellor. Other roles that he created for himself are those of the playwright Fernando de Zárate and the Dutch business man Willem Van Billem.

${ }^{6}$ Oelman (1986) believes that he did know Hebrew. Yet, even though it is clear that Enríquez Gómez knew some Hebrew words, such as those included in a satirical poem, «Romancillo», written in France and targetting the Inquisition and its informers, and even though it is equally clear that he was acquainted with Jewish prayers, perhaps in Spanish translation, the extent of his knowledge is not known. See my article, «Antonio Enríquez Gómez y el Templo de Salomón» (2000).

7 NALLE (1992:148) mentions that Dueñas' work was popular with a group of conversos in Cuenca. The inquisitional records of Enríquez Gómez' family, the De Mora, support this statement; Francisco de Mora, for example, when asked what he had been reading prior to his arrest, stated that he had read Dueña's book and Amadis de Gaula. See Archivo Diocesano de Cuenca [= ADC], Inquisición, Leg. 315, núm. 4562 (1588): «Francisco de Mora, Quintanar de la Orden; Judaísmo; Relajado». Dueñas' Consolación is a sort of «lives of the saints» a la judaica and recounts the stories of Old Testament heroes and heroines who triumphed over adversity.

8 The Biblia en lengua española, known as the Ferrara Bible, translated from the Hebrew by Abraham Usque and Yom Tob Athias and originally printed in Ferrara, Italy, in 1553, at the expense of Doña Gracia Mendes, was reprinted in 
quotations from Cipriano de Valera's Protestant Bible of 1602, legally available to him in France ${ }^{9}$.

Although Luis dado de Dios purports to be a gloss of 1 Samuel, Enríquez Gómez feels quite free to elaborate upon his source, if it suits his purpose. Accordingly, though the first line of 1 Samuel 1 reads, «Hubo un varón de Ramathaim», he adds the word «justo» and begins his work with the sentence: «Hubo un varón justo de Ramathaim». In this way, while acknowledging the sobriquet, «le juste», of Louis XIII, he skillfully moves the monarch from the title page to the text and links him to Elcanah, the father of Samuel and the original subject of the Biblical phrase. Furthermore, through this simple one-word addition to the quotation contained in the first sentence of his book, he sets the tone for the rest of the work. Thus, the author announces his purpose from the start; justice is clearly his subject.

Enríquez Gómez wrote two separate versions of this text for two separate audiences. At signature S or pages 137-145, he substituted one version for the other in seemingly seamless fashion, the lead in and lead out are identical. One version reached England, the other was widely distributed in France, and both have been found in Spain and Portugal ${ }^{10}$. Version A applauds the separation of Portugal from Spain, and $B$, in the course of advising the ruler on good governance, attacks the Holy Office of the Inquisition.

Amsterdam in 1630 and was, therefore, accessible to Marranos in Rouen through the illegal traffic of forbidden books between the two cities. DOUBLET (1979:3435) lists a number of early Bibles -Catholic, Protestant and Jewish- which are contained in the Municipal Library of Rouen, the city in which Enríquez Gómez lived at the time he wrote Luis dado de Dios.

9 Following the issuance of the Edict of Nantes in 1598, Protestant Bibles were legal in France. When quoting from the Old Testament, Enríquez Gómez always utilized that of Cipriano de Valera; therefore, all further Biblical citations in the present essay imply that version.

10 Based on the copies that I had seen in the British Library and in several libraries in Paris (Bibliothèque Nationale, Arsenal, Mazarine, Sorbonne and Sainte Geneviève), I announced the existence of the two distinct versions (1976:817, n. 46); later, after locating both versions in the Biblioteca Nacional, Madrid, and after discovering a partially autograph manuscript of the work in the Biblioteca Nacional, Lisbon, I devoted a whole article to the subject (1981). Quite independently from my discoveries, Luis Reis TORGAL encountered both versions in the library of the Universidade de Coimbra and published his findings; he also reproduced very useful facsimiles of the two disparate texts (1979). 
Enríquez Gómez prepares carefully for the attack and introduces the topic beforehand. He elaborates upon a speech by Samuel (p. 136), who exhorts the people of Israel to cast aside false idols: «Y HABLO SAMUEL A TODA La Casa de Israel, diciendo: Si queréis de todo vuestro corazón bolberos al Señor, quitad, quitad a dioses agenos o Astaroth de entre vosotros». Next the Spaniard, without marking any transition or giving any indication that what follows are not the words of 1 Samuel 7:3, proceeds to write of right rule and of the monarch's responsibility in preserving justice: «El príncipe Sabio deue amonestar», he advises, «a las principales cabezas del imperio, no sólo que amen la justicia en público, sino que la guarden siempre». He next reprimands judges, «Oýd reyes, aprended juezes de la tierra, dadme oýdos los que gobernáis los pueblos, y los que honráis la multitud de las gentes. De Dios tenéis el Señorío y la potestad del altíssimo. Quitad, quitad, jueces del mundo, de Astaroth de entre vosotros», Astaroth, that is, the false goddesses of ambition.

At this point, on line 2 of page 137, the two texts diverge; in version B, Enríquez Gómez, calling for divine intervention, continues his warning to judges:

El hará inquisición de Vuestros juicios y de vuestras obras, y escrudinará vuestros consejos. Porque siendo Ministros del Reyno, no jusgasteis Rectamente, ni guardasteis la ley, ni caminasteis conforme a su consejo. Espantoso y de repente vendrá sobre vosotros el juicio del todo poderoso: A vosotros, tyranos, se endereçan mis palabras; con vosotros hablo: Espantosa palabra es la que dice, Y DIOS HARÁ INQUISICIÓN DE VUESTROS JUICIOS.

This last phrase, the repeated «Y Dios hará inquisición de vuestros juicios», fairly leaps off the page, as the words printed in large capital letters stand out from the rest of the text.

At first glance, this sentence seems to be attributed to Samuel and the fact that it is set off by a colon could easily be overlooked. But just who says, «Con vosotros hablo»? In actuality, these words appear to be those of Enríquez Gómez who speaks for his God, a stern Old Testament God; so closely does the author associated himself with his God, that it is difficult to differenciate between the two. In truth, none of these sentiments are expressed by Samuel, the lawgiver; the entire speech is a pastiche of several verses 
from the Book of Wisdom from the Jewish Apocrypha. The following excerpts from Wisdom will sound familiar:

Buelve a su tema principal de exhortar a los gobernadores del mundo al estudio de la verdadera sabiduría, amenazándoles con el riguroso juyzio que los espera, si la dexaren; 2] Oýd, pues, oh reyes, entendéis, y aprended juezes de todos los términos de la tierra; 3] Dad oýdos los que mandáys a los pueblos ... 4] Porque de dios tenéys el señorío y la potestad por el altíssimo, que hará inquisición en vuestras obras, y escudrinará vuestros consejos; 5] Porque siendo ministros de su reyno no jusgasteis rectamente, ni guardasteis la ley, ni caminasteis conforme a su consejo; 6] Espantoso y de repente vendrá sobre vosotros ... 7] A vosotros, pues, tiranos, se enderezan mis palabras porque aprendáys sabiduría. [Emphasis mine.]

In his paraphrase of this unacknowledged Biblical passage inserted into the text of Luis dado de Dios, Enríquez Gómez has deliberately substituted the word «justicia» for «sabiduría» in order to further his pursuit of justice. By not revealing that he is indeed paraphrasing the Book of Wisdom, which switches from the third person -«que hará inquisición en vuestras obras», «... de vuestros iucios»- to the first person singular - «se endereçan mis palabras»-, the author aligns his thinking and his words with the wisdom of God.

By imitating the thunderous voice of God in the act of warning monarchs to select their ministers wisely and urging judges to observe the law, Enríquez Gómez nevertheless exposes his own feeling of helplessness in the presence of the injustice of the world and reveals his need to invoke the threat of divine retribution. At one time, as a young man, he seemed to have believed that earthly justice was attainable: in his own life he had exhibited such faith in civil law that he believed that he could sue the Inquisition and win, as he attempted to recover his dead mother's estate which had been illegally seized along with that of his Judaizing father ${ }^{11}$; and in his plays he had demonstrated that the heroes he created could successfully plead their cases in court. But in Luis dado de Dios, it is God, not man, Who dominates and divine justice which

11 Archivo Histórico Nacional (Madrid), Inquisición, Leg. 3658, núm. 16 (1624): «Antonio Enríquez Gómez contra Miguel Fernández de Fonseca por 131 libras de seda». Unlike his father, the poet's mother was Christian. 
suceeds. Still, at this point in Enríquez Gómez' writings, divine justice is seen as effecting events on earth; that is, earthly justice will prevail if rulers heed the word of God.

The Inquisicion de Lucifer is the word made flesh. With this work Enríquez Gómez carries out the threat expressed in Luis dado de Dios, «Dios hará inquisición de vuestros juicios». The Spaniard has so decreed and he vigorously condemns the Holy Office for perverting the true nature of justice and for daring to substitute its judgment for that of God.

This exceedingly comic, inventive prose satire, which could not be more different from the serious and ponderous Luis dado de Dios, was discovered in manuscript by B. N. Teensma in the 1970's. The Dutch scholar was examining records of seventeenthcentury Portuguese merchants in the Municipal Archive of Amsterdam when he discovered a hither-to-unknown and unpublished collective volume of Jewish works amassed by one Abraham Idaña or Gaspar Méndez de Arroyo, as he was known in the Christian world. The entire Idaña collection is dated 1692, though the last interior date, contained in an enclosed letter, is $1686^{12}$, by which time Enríquez Gómez (1600-1663) was long dead.

The Inquisición de Lucifer, in a different hand from the other manuscripts in the collection, is, in addition, the only one not overtly Jewish ${ }^{13}$. Divided into two «Sueños» or «Visions» in imitation of Quevedo, this undated work may have been written at two different times; the «Sueño Primero» not only exhibits many of the same references and lexical obsessions visible in the author's

\footnotetext{
12 An inscription on the flyleaf of the inside back cover yields the date 1692; presumably the notation was written by "Yshak Ydaña». Yshak (Isaac), a son of Abraham Idaña, was born in Douvenit in 1653, and when he married in Amsterdam in 1675, his father was his witness (VERDOONER - SNEL c. 1992) -an indication that Abraham had left Spain long before 1686 and had been in Holland several years before completing his collection. According to TEENSMA (1977), the father, who was born in Badajoz in 1620, left Spain in 1660 and died in Holland in 1690. None of the above information reveals when or where Enríquez Gómez entrusted the elder Idaña with the manuscript of the Inquisición de Lucifer.

13 The other items include: 1) a letter to Juan Baldés about Jewish life in Amsterdam; 2) two dialogues between Obadía ben Ysrrael and his brother Andrés Antonio; 3) some verses about the unity of God and another letter for Juan Baldés; 4) a treatise on the obligation to give alms to the poor; 5) praise of the author, a warning against false oaths, and an act of contrition for Yom Kippur; and 6) three of David's psalms.
} 
works of the 1640's, the period of his intense publishing activity in France, but also contains, almost word for word, two passages from a section appended to his Torre de Babilonia of $1649{ }^{14}$.

The «Sueño Primero» may have been written as early as 1643 , the only year for which there is no visible literary activity on the part of the Spaniard, who claimed that he wrote nine books in the 1640's, one a year: «Hacen nueve volúmenes en prosa y verso, todos escritos desde el año cuarenta al de cuarenta y nueve, a libro por año u a año por libro» (Prologue, Sansón Nazareno ${ }^{15}$ ). If this is the case, this «Sueño» would be an embryonic form of $E l$ marqués de la Redoma, the novella perhaps written in 1647 (Gendreau-Massaloux and Rose) ${ }^{16}$ and later attached to the Torre de Babilonia.

The «Sueño Segundo» is initially more serious and perhaps more personal, containing what may be autobiographical material, so real does the author's anger appear; in a somber scene, quite different in tone from the rest, a group of lecherous inquisitors torture and sexually torment a young girl, a virgin, whose story the author's parents may have related to him ${ }^{17}$.

Elsewhere, this «Sueño» is stylistically reminiscent of the merry farce, El valiente Campuzano of 1660, the first of his plays to be published under the alias of Fernando de Zárate and the only Zárate work to be published prior to his incarceration. Therefore, it is not unreasonable to suggest that the «Sueño Segundo» may

14 The passages in question are contained in the Appendix to ROSE - KERKHOF's edition of the Inquisición de Lucifer.

${ }^{15}$ For more on this Prologue, see the studies of Porqueras Mayo (1968) and PROFETI (1982).

${ }_{16}$ We based our suggestion that the novella was written in 1647 on the date which indicates when its protagonist, the Marqués de la Redoma, was liberated from his flask prison.

17 Among those relatives tried in 1580 in Quintanar de la Orden, several were «doncellas» or virgins; their experiences could have been transmitted orally from one generation to another, within Enríquez Gómez' immediate family. For these trials, see ROSE (1987), for references to the following documents: ADC, Inquisición, Leg. 316, núm. 4572 (1588): «Luisa de Mora, doncella, hija de Diego de Mora, Quintanar de la Orden; Judaísmo; Incompl.»; Leg. 317, núm. 4585 bis (1588): «Isabel de Mora, doncella, hija de Diego de Mora, Quintanar de la Orden; Judaísmo; Reconciliada»; Leg. 327, núm. 4689 (1590): «Isabel de Mora Carrillo, doncella, hija de Lope de Mora, Quintanar de la Orden; Judaísmo; Reconciliada»; and Leg. 331, núm. 4734 (1591-1592): «Luisa de Mora, doncella, hija de Juan de Mora, difunto, Huete; Judaísmo; Reconciliada». 
be contemporary with this play and may have been written toward the end of the author's life, perhaps as late as 1662 or 1663, when Enríquez Gómez himself was a prisoner of the Inquisition.

The basic conceit in the Inquisicion de Lucifer is that the devils, who have their own inquisition, are more just and more fair than their earthly counterparts. In this world turned upside-down, where religious zealots keep their glance on the ground because they do not dare to raise their eyes to heaven, Lucifer is God's agent. Through him, the author is able to expose the infernal operations of the earthly Inquisition; magically, Barrademonio, the Inquisitor General, is able to slip inside the bodies of victims subjected to interrogation, and through this bodily invasion, to torment their tormentors, in protest of the workings of the Holy Office.

Making Lucifer God's agent is an interesting and ironic commentary on Enríquez Gómez own dramatic work, for the devil, as an evil machinating character, figures prominently in the author's late Christian plays published under the name of Zárate ${ }^{18}$.

In the Inquisición de Lucifer, certain toponymic references, to «Peralvillo» and to the «Valle de Josafá», once again reveal the author's attitude toward justice. The narrator, who accompanies the rather jaded Inquisitor General on his rounds, peers into the dwelling of a false beato and discovers a private ossiary, where even the curtains are trimmed with bones (p. 24). This appalling sight causes him to comment, "Yo presumí que repentinamente habíamos dado en Peralvillo, según la gran cantidad de calaveras y huesos que había por todo el aposento» (p. 33).

Peralvillo was a vineyard estate near Ciudad Real where the Santa Hermandad, the Holy Brotherhood or rural police, tortured

${ }^{18}$ Basing his opinion, in part, on the playwright's depiction of the devil in those comedias performed and/or published in Spain after his clandestine return, DILLE (1987 and 1988) expresses his belief that Enríquez Gómez became a true Christian in later life. My own position is that the depiction of the devil in Inquisicion de Lucifer would seem to obviate that possibility; it is more likely that the playwright dramatized Christian material as a kind of insurance policy in case of his arrest by the Holy Office. All the documents, the confessions of the author's father and a cousin, as well as his own confession, indicate that he was Jewish. Although there is abundant material on this subject, his actual trial has been lost. In addition, the recent book by GARCÍA-ARENAL - WIEGERS (1999) should make abundantly clear the extent to which «exiled» Sephardic Jews were willing to feign conversion in order to live/and or work in Spain. 
and killed prisoners: «Un pago junto a Ciudad Real, donde la Santa Hermandad haze justicia de los delinqüentes que pertenecen a su jurisdición, con la pena de saetas» (Covarrubias s.v. Peralvillo; emphasis mine). A proverb, Covarrubias also reminds us, describes the penal process and demonstrates how justice was meted out by the Holy Brotherhood: «La justicia de Peralvillo, que después de asaeteado el hombre le fulminan el processo». In Correas' version of the proverb, the felon is hanged, not killed by arrows ${ }^{19}$, but the result is the same; after the prisoner is executed, the sentence is read over his lifeless body. As the devilish Inquisitor General in the Inquisición de Lucifer remarks, «Este Peralvillo a lo divino júrese de cementerio y no de tribunal» (p. 63).

There are three appearances of the Valle de Josafat in the Inquisición de Lucifer. The narrator expresses his astonishment and relief at having survived a difficult situation (p. 3): «Quedé como si hubiera pasado por el valle de Josafá». The Inquisitor General of the devils swears, on his future salvation, that his Inquisition punishes the souls of the offenders, not their bodies ( $p$. 34): «A vosotros toca castigar los cuerpos y a nosotros las almas, y de no ser así, en el valle de Josafá os lo diremos». The third reference to the Valle de Josafá joins the reference to «Peralvillo a lo divino» (above), in which the author attacks the legitimacy of the Holy Office (p. 63); here, after being asked his parents' religion, a prisoner accuses the inquisitors of wanting to destroy the reputation of the dead: " $i Y$ quieren vuesas señorías antes de tiempo llamarles a juicio, quieren hacer de este Tribunal el valle de Josafá, siendo de herejía?».

The reference to the Valle de Josafá (Valley of Jehoshaphat) is from the Book of Joel, a minor prophet, where, at verse 3.2, Jehova declares, «Juntaré todas las gentes y harélas descender al valle de Josaphat y allí entaré en juicio con ellos a causa de mi pueblo, y de Israel mi heredad, a los cuales esparcieron entre las naciones, y partieron mi tierra», and again, at 3.12, «Las gentes se despierten y suban al valle de Josaphat; porque allí me sentaré para juzgar todas las gentes de alrededor». The Book of Joel is a work of exile which announces Jehova's intention to bring to reckoning on

19 CORREAs (1627) writes that «la xustizia de Peralvillo, ke después de ahorkado el onbre le leen la sentenzia del delito»; he then classifies the expression, "Véate komo otros en Peralvillo», as «Pulla i maldizión por ahorkado de la Ermandad». 
Judgment Day, in the Valley of Josafat, the enemies of Israel who have scattered His people to the far ends of the earth, to the Iberian Peninsula, where inscribed on a wall of the Synagogue of the Tránsito in Toledo, is a verse from Psalm 61 which proclaims, «desde el cabo de la tierra clamaré a Ti» ${ }^{20}$.

Today, according to the Diccionario de la Real Academia Española the expression, «iHasta el valle de Josafat!» means ‘ $i$ Hasta el día del Juicio!' and is uttered by those who have no hope of ever seeing one another again. In the past, the expression must have had more overt religious significance, if one takes into consideration examples of ancient usage which have survived into the twentieth century. Samuel Schwartz (1925:86) records the following two examples from among the prayers for the dead offered up by those Marranos who had remained behind, isolated in Portugal's hill towns, and who believed themselves to be the only Jews left in the world. The first prayer is clearly ceremonial:

Ao Vale de Jusafá irás, um leão encontrarás: Se te pedir senha, toma, da-lhe dinheiro (aqui lhe passam por a vista com uma moe$d a$ ). E se te pedir carne, da-lhe pão (aqui lhe passam por a vista com um pedaço de pão). Se te procurar de que Lei es, diz-lhe que es da Lei de Moysés; que te deixe passar, livre e desemparaçado, para onde Deus te mandar! Se te preguntar quem te compraz [quem te amortalha], diz-lhe que foi uma hebreia que neste mundo ficou, e que se mais bem não te fêz foi porque mais não sabea $\left[\right.$ sabia ${ }^{21}$.

The second prayer, which again deals with the washing and laying out of the corpse, also invokes the devil:

Irás e virás, ao campo de Josafat, o diabo encontrarás e lhe dirás:

\footnotetext{
${ }^{20}$ Sephardic Jews felt that the Diaspora, which had exiled them from the Holy Land and scattered them to the ends of the earth, to Spain and Portugal, was God's just punishment for their sins: Deut 28:64, «Y Yehová te esparcirá por todos los pueblos, desde el un cabo de la tierra hasta el otro cabo de ella».

21 'When you go to the Valley of Josafat, you will encounter a lion: If you are asked for a sign, give him money [at this point, pass the coin within his sight]. And if you are asked for meat, give him bread [here pass the piece of bread within his sight]. If you are asked what Law, what religion, you belong to, tell him that you believe in the law of Moses; tell him to let you pass, free and unemcumbered, to go where God ordered you. If you are asked who laid out your corpse, tell him that it was a Jewish woman who remained in this world and that if she didn't do it better, it was because she didn't know how' (translation mine). GiTLIzT' translation (1996) differs radically from mine.
} 


$$
\begin{aligned}
& \text {-iSalta atraz, Satanaz! } \\
& \text {-iQue traz? } \\
& \text { - Agua para me lavar, } \\
& \text { pano para me limpar } \\
& \text { e oferta para te atirar }{ }^{22} \text {. }
\end{aligned}
$$

As David Gitlitz (1996) has shown, such references to the ritual bathing of the corpse and to the objects safeguarding the dead on their last journey, accurately reflect Jewish funeral practices in medieval Spain and Portugal, practices which lingered on in inquisitional times both in the Peninsula and in Latin America. Other such prayers which refer to the valley of Josafat are still voiced today by Crypto-Jews and descendants of New Christians in Belmonte and other Portuguese towns ${ }^{23}$.

Surely in Enríquez Gómez' day such prayers still existed in Spain and among the Spanish and Portugueses exiles in France, and surely, given his knowledge of Jewish ritual, including burial practices ${ }^{24}$, he was aware of the prayers for the dead. Perhaps they even inspired him to invent his own dialogue with the devil, his Inquisición de Lucifer.

The expressions, Peralvillo and Valle de Josafá, are not confined solely to Enríquez Gómez' Inquisición de Lucifer: for example, Peralvillo appears three times and Valle de Josafá four times

22 'When you are in the land of Josafat, / you will encounter the devil and will say to him: / «Get thee behind me, Satan!»/ «What are you carrying?»/ «Water to wash myself, / a cloth to clean myself, / and an offering to make a deal with thee'» (translation mine).

${ }^{23}$ Manuel da Costa FONTES was kind enough to send me the following Christian Portuguese prayers which he had collected and published. Each contains a remnant of what originally must have been a Crypto-Jewish prayer: (1979) «Tu irás e não temerás / pelo caminho de Josafás. / O inimigo da cruz encontrarás / e tu le dirás: —Vai-te, arreca, Santanás»; (1983) «Quando deste mundo me for, / juizo d'alma encontrarei / no vale de Judafás»; «Morrerás e não temerás / no vale de Josafá te cairás / e o inimigo da fé encontrarás / e le dirás: / —Enganado vens, Satanás»; and «Morrerás, não temerás / ao vale de Josafás sairás, / o demónio encontrarás / e tu le dirás: / -Arreda-te de mim, / vai a Santanás». For more information on contamination and conflation of orally transmitted Jewish prayers in Portugal and among Portuguese speakers in other lands, see FONTES (1992 and 1993).

${ }^{24}$ In a mock series of offenses against the faith - «mataba al gallo si cantaba a las diez, echaba cenizas al perro si aulaba en la calle»- committed by a Judaizer in Inquisición de Lucifer, one also encounters accusations involving burial rites actually leveled by the Holy Office at its suspect population: «se mandaba lavar después de muerto y mandaba enterrarse en tierra virgen, ponía camisa nueva a los difuntos» (ENRÍQUEZ GómEZ 1992). 
in El siglo pitagórico of $1644^{25}$; and in the Torre de Babilonia, they are united in the same sentence (p. 160): «No alegue con los vibos sino con los muertos ... [el que] tiene su autoridad en Peralvillo, y si algún discreto le caluniare la aprueba, remítate al valle de Josaphá», thus demonstrating that the two locations were not far from each other in Enríquez Gómez' mind, where they are linked in a cause and affect relationship: the failure of earthly justice necessitates the coming of Judgment Day when God will redress all the wrongs committed against His people, after death.

Indeed, Enríquez Gómez' references to Peralvillo and to the Valle de Josafá, whether satirical, sardonic or serious, here and elsewhere, seem to indicate his increasing loss of faith in earthly justice, where the sure and deadly punishment executed by the Holy Office of the Inquisition prevailed. Clearly he shares the opinion voiced, as a question, by his Inquisitor General of the Holy Office of Hell: « $i Y$ quieren vuesas señorías antes de tiempo llamarlos a juicio, quieren hacer de este Tribunal el valle de Josafá, siendo el valle de la herejía?» (p. 63).

The author further suggests that until such time as the Inquisition, which challenges the authority of God, can be curtailed or abolished, justice can only be found in the hereafter, in the Valle de Josafá, where He sits in judgment of the enemies of Israel ${ }^{26}$.

Despite this pessimistic view of human justice, the Inquisición de Lucifer concludes on an optimistic note, as the satanic Inquisi-

25 The following quotations are from AMIEL's edition of this work, which may be contemporary with Inquisición de Lucifer: «le deseaban ver en Peralvillo» (p. 56); «irás en tiempo a Peralvillo» (p. 261); «guiándole el verdugo lazarillo, / guardajoyas de todo Peralvillo» (p. 265); «que en Josafá sin duda nos veremos» (p. 32); «todos hemos de resucitar en el valle de Josafá» (p. 125); «en Josafá te lo dirán de misas» (p. 209); «en el valle de Josafá nos hemos de ver todos» (p. 275). References to Josafá are also present in his Sansón Nazareno (1656), an epic poem which Enríquez Gómez all but finished in 1649 before he left France for Spain: «Aquellos huesos, porque más te asombre / del juicio universal el Nuevo Mundo, / serán en Josafá, luz de las gentes, / dè la resurrección cuerpos vivientes» (VII51); «Este, que alienta del sophar los ecos, / trompa de Josafá, valle fecundo, / a cuya fuerte voz los huesos secos / vienen al juicio universal del mundo; / ... / de los doce profetas, el segundo, / es el justo Joel» (VII-59).

26 Consider what the inquisidor charged with the staging the event wrote in his report to his king, Carlos II, in which he compared the auto de fe to Judgment Day: "porque fue tal este [auto de fe] que se propiamente compara a lo que se verá en el espantoso día del universal juicio» (Olmo 1680:83). But to Enríquez Gómez, Olmo and others like him would be the ones to be judged by God in the Valle de Josafá as enemies of His people, as Joel had prophesied. 
tor General vows to investigate the Holy Office: he ardently hopes «que se llegue el tiempo de ampliar su jurisdicción en el completo juicio de la ... Inquisición de los ministros del siglo» ${ }^{27}$, those who direct the earthly Inquisition. But then we know that, according to another tradition, the Christian tradition, the devil is a Jew; in this case, a Jew who would investigate the Holy Office of the Inquisition and sit in judgment of it.

Perhaps, the Inquisición de Lucifer was Enríquez Gómez' last laugh; he knew that he had demonstrated that Jews were fair and incorruptible, in a word, more "Christian» than the so-called Christians who oversaw the workings of the Holy Office. In a word, the law of Moses -to which so many of his relatives were accused of adhering and for which so many were slain- the Jewish law, the law of the Torah, was God's law.

Such an attempt to curtail the power of the Inquisition did occur, in Portugal (Saraiva; Gendreau-Massaloux - Rose). Antonio Enríquez Gómez, together with his close friend Manuel Fernandes Villareal, the consul of the Jewish Nation in France, worked with the leaders, the Jesuit António Vieira of Portugal and the Rabbi Menasseh ben Israel of Amsterdam, of a movement to achieve such a goal and to establish a punishment-free syncretic religion which would embrace both Judaism and Catholicism.

They were successful: in 1649, João IV, the king newly-restored to the Lusitanian throne, signed the papers necessary to implement the decrees which would have permitted Portuguese Jewish merchants and others to return to their native land and to worship as they pleased. But the Portuguese Inquisition proved too strong for the king and the reform movement ultimately failed. Upon his triumphant return to Portugal in 1649, Fernandes Villareal was first received as a hero and honored for his service to his country, and then subsequently jailed, tried and convicted as a Judaizer, though awarded the priviledge of being garroted before being burned at the stake in an auto-da-fe in 1652.

As to Enríquez Gómez, after secretly returning to Spain in 1649 and eluding the Inquisition for a number of years, he was captured

\footnotetext{
27 By «siglo» Enríquez Gómez means the secular world, bounded by time. This use of the word abounds in the works of the author; cf. his Loa sacramental de los siete planetas.
} 
in Seville and died in an inquisitional jail in 1663, in the third year of his detention, before he could be sentenced. What might he have said in his defense at his lost trial?: « ¡Hasta el valle de Josafá!».

\section{BIBLIOGRAPHY}

Amiel, Charles: See EnRíquez Gómez 1977.

Biblia en lengua española, Traduzida por Abraham UsQUE et Duarte Pinhel. Amsterdam: 5390 [1630].

La Biblia: que es los sacros libros del viejo y nuevo Testamento, Segunda edición, revista y conferida con los textos Hebreos y Griegos y con diversas traducciones; Trans. Cipriano de VALERA, after the version of Cassidoro de la ReINA. Amsterdam: Lorenzo Jacobi, 1602.

COHEN, Louise G.: See EnRÍQuez Gómez 1974.

CORREAS, Gonzalo. Vocabulario de refranes y frases proverbiales. Madrid: 1627.

Covarrubias Horozco, Sebastián de. Tesoro de la lengua castellana o española. Madrid: Luis Sánchez, 1611.

Dille, Glen F. «The Christian Plays of Antonio Enríquez Gómez», Bulletin of Hispanic Studies 44 (1987) pp. 39-50.

- «The Tragedy of Don Pedro: Old and New Christian Conflict in $E l$ valiente Campuzano», Bulletin of the Comediantes 35 (1983) pp. 97 109.

-. Antonio Enríquez Gómez. Boston: G. K. Hall, 1988.

DOUBLET, Arlette. Catalogue du fonds Ancien espagnol et portugais de la Bibliothèque Municipale de Rouen, 1479-1700. Rouen: LECERF, 1970.

DueÑas, Juan de. Espejo de consolación de tristes. Palencia: 1554.

Enríquez Gómez, Antonio. Fernán Méndez Pinto, Comedia famosa en dos partes; Intro. and Ed. Louise G. COHEN, Francis M. ROGERS and Constance H. Rose. Cambridge, Mass: Harvard University, 1974.

-. Inquisición de Lucifer y Visita de todos los diablos; Intro. and Ed. Constance Hubbard Rose and Maxim. P. A. M. Kerkhof. Amsterdam: Rodopi, 1992.

- Loa sacramental de los siete planetas; Intro. and Ed. Constance Hubbard Rose, with Timothy Oelman. Exeter: University of Exeter, 1987.

-. Luis dado de Dios a Luis y Ana: Samuel dado de Dios a Elcaná y Ana. Paris: René Baudry, 1645. 
-. Política angélica. Primera Parte, dividida en 5 partes. Rouen: Laurent Maurry, 1647.

-. Sansón Nazareno, poema heroico. Rouen: Laurent Maurry, 1656.

-. El siglo pitagórico y Vida de don Gregorio Guadaña. Rouen: Laurent Maurry, 1644. Modern editions: Charles AMIEL, Paris: Ediciones Hispanoamericanas, 1977; and Teresa de SANTOS, Madrid: Cátedra, 1991.

-. La torre de Babilonia. Rouen: Laurent Maurry, 1649.

-. (Fernando de Zárate). Los filósofos de Grecia, In Parte diez y nuevas de comedias nuevas y escogidas de los mejores ingenios de España. Madrid: Pablo de Val, 1662.

-. (Fernando de Zárate). The Perfect King: El rey más perfeto; Ed. and Trans. Michael McGAHA. Tempe, Arizona: Bilingual Press, 1991.

-. (Fernando de Zárate). El valiente Campuzano, In Pensil de Apolo, en doce comedias nuevas de los mejores Ingenios de España. Parte catorce. Madrid: Domingo García y Morrás, 1660.

FonTes, Manuel da Costa. «Four Portuguese Crypto-Jewish Prayers and Their 'Inquisitorial' Counterparts», Mediterranean Language Review 6-7 (1993) pp. 67-104.

—. «Mais orações criptojudias de Rebordelo», Revisa da Universidade de Coimbra 37 (1992) pp. 457-469.

-. Romanceiro da Ilha de S. Jorge; Pref. Samuel G. ARMISTEAD e Joseph H. SILverman. Coimbra: Acta Universitatis Conimbrigensis, 1983.

-. Romanceiro Portugues do Canadá; Pref. Samuel G. ArmisteAd e Joseph H. Silverman. Coimbra: Por ordem da Universidade, 1979.

GARcía-ArenAL, Mercedes, and Gerard WiEgers. Entre el Islam y Occidente: Vida de Samuel Pallache, judio de Fez. Madrid: Siglo Veintiuno de España Editores, 1999.

García Gómez, Angel M. The Legend of the Laughing Philosopher and its Presence in Spanish Literature (1500-1700). Córdoba: Universidad de Córdoba, 1984.

GARCía VAldeCASAS ANDRADE, José. «Las academias morales» de Antonio Enríquez Gómez: Críticas sociales y jurídicas en los versos herméticos de un "judío" español en el exilio. Sevilla: Universidad de Sevilla, 1971.

Gendreau-Massaloux, Michèle, and Constance Hubbard Rose. «Antonio Enríquez Gómez et Manuel Fernandes Villareal: Deux destins parallèles, une vision politique commune», Revue des Etudes Juives 136 (1977) pp. 368-388.

Gitlitz, David M. Secrecy and Deceit: The Religion of the Crypto-Jews. Philadelphia - Jerusalem: The Jewish Publication Society, 1996. 
Kerkhof, Maxim. P. A. M.: See Enríquez Gómez 1992.

—. "La "Ynquisiçion de Luzifer y Uisita de todos los diablos", Texto desconocido de Antonio Enríquez Gómez. Edición de unos Fragmentos», Sefarad 38 (1978) pp. 319-331.

Kramer-Hellinx, Nechema. Antonio Enríquez Gómez: Literatura y sociedad en "El siglo pitagórico y Vida de don Gregorio Guadaña». New York: Peter Lang, 1992.

MCGAHA, Michael: See EnRÍQuez Gómez 1991.

NAlle, Sara T. God in La Mancha: Religious Reform and the People of Cuenca, 1500-1650. Baltimore \& London: Johns Hopkins University, 1992.

Oelman, Timothy: See EnRíquez Gómez 1987.

-. Romance al divín mártir, Judá Creyente [don Lope de Vera y Alarcón] martirizado en Valladolid por la Inquisición. Rutherford: FairleighDickinson University, 1986.

Olmo, José del. Relación del auto general de la fee que se celebró en Madrid en presencia de SS.MM. (que Dios guarde) el día 30 de junio de 1680.

Pérez Ramírez, Dimas. Catálogo del Archivo de la Inquisición de Cuenca. Madrid: Fundación Universitaria Española, 1982.

Porqueras Mayo, Alberto. El Prólogo en el manierismo y barroco españoles. Madrid: CSIC, 1968.

Profeti, Maria Grazia. «Un esempio di critica 'militante': Il prologo al Sansón Nazareno di Enríquez Gómez», Quaderni di Lingue e Letteratura 7 (1982) pp. 203-212.

RÉVAH, I. S. «Un pamphlet contre l'Inquisition d'Antonio Enríquez Gómez: La seconde partie de la Política Angélica (Rouen, 1647)», Revue des Etudes Juives 121 (1962) pp. 81-168.

Rogers, Francis M.: See EnRíquez Gómez 1974.

Rose, Constance H. (Hubbard): See ENRÍQuez Gomez 1974, 1987, 1992; see also Gendreau-MASSALOUX.

—. «Antonio Enríquez Gómez y el templo de Salomón». In Encuentros y desencuentros: Spanish-Jewish Cultural Interaction throughout History, pp. 413-429. Tel Aviv: University of Tel Aviv, 2000.

-. «Antonio Enríquez Gómez and the Literature of Exile», Romanische Forschungen 85 (1973) pp. 63-77.

-. «Las comedias políticas de Antonio Enríquez Gómez», La Torre (Univ. of Puerto Rico) 118 (1982) pp. 183-196.

-. «Dos versiones de un texto de Antonio Enríquez Gómez: Un caso de autocensura», Nueva Revista de Filología Hispánica 30 (1981) pp. 534545. 
-. «The Marranos of the Seventeenth Century and the Case of the Merchant Writer Antonio Enríquez Gómez», In The Spanish Inquisition and the Inquisitorial Mind, Ed. Angel ACALÁ, pp. 45-62. New York: Columbia University, 1987.

-. «Who Wrote the Segunda parte of La hija del aire?», Revue Belge de Philologie et d'Histoire 54 (1976) pp. 797-822.

SANTOS, Teresa de.: See ENRÍQuez GómEZ 1991.

SARAIVA, António José. «António Vieira, Menasseh ben Israel et le cinquième empire», Studia Rosenthaliana 6 (1972) pp. 25-56.

Schwartz, Samuel. Os cristãos novos em Portugal no século $X X$. Lisboa: Associação dos Arqueólogos, 1925.

TeEnsma, B. N. «Fragmenten uit het Amsterdamse convoluut van Abraham Idaña alias Gaspar Méndez del Arroyo», Studia Rosenthaliana 9 (1977) pp. 127-156.

TORGAL, Luis Reis. «A literatura 'marrânica' e as 'edições duplas' en António Henriques Gomes (1600-1663)», Biblos 55 (1979) pp. 197-228.

Verdooner, Dave and Harmen Snel. Trowen in Mokum: Jewish Marriages in Amsterdam 1585-1750, Vol. I. Der Haag: Gegevens Koninkluke Biblioteek, c. 1992.

\section{RESUMEN}

Un tema que une la obra de Antonio Enríquez Gómez (1600-1663), un marrano español que vivió un largo exilio en Francia, es la búsqueda de la justicia: personal, terrestre y divina. Al examinar dos comedias y dos tratados suyos, sobre todo su Inquisición de Lucifer y Visita de todos los diablos (s. f.), un texto recién descubierto en Amsterdam, se puede ver cómo el autor desarrolla su tesis empleando dos topónimos antitéticos: «Peralvillo», que muestra la falta de justicia en este mundo, y «el valle de Josafá», donde Jehová dispensará la justicia divina y castigará a los enemigos de su pueblo, el pueblo judío.

\section{SUMMARY}

One theme uniting the work of Antonio Enríquez Gómez (1600-1663), a Spanish Marrano who resided in France for many years, was his search for justice-personal, earthly and divine. By examining two of his plays and two treatises, above all the comically sardonic Inquisición de Lucifer y Visita de todos los diablos (n.d.), a text recently discovered in Amsterdam, it is possible to see that this author bases his thesis, in part, on two geographical locations: «Peralvillo», which symbolizes the miscarriage of earthly justice, and "el valle de Josafá», where divine justice will prevail. 